Jan Carson - Andrea Rožić

\title{
Priče s razglednica
}

\section{Na Isusa}

„Ošišaj me na Isusa“, kaže on.

Ima sliku u mobitelu za slučaj da frizerka ne zna kako Isus izgleda. Ona mu uzme mobitel iz ruke i prinese ga licu praveći se da se koncentrira. Točno zna kako Isus izgleda. Vidjela ga je dovoljno puta na kipovima i vitrajima. Kad je bila mlađa, imala je ilustriranu Bibliju sa slikama u boji: mali debeli Isus u slami s magarcem, Isus koji izvodi čuda u svjetloplavim haljama, umirući Isus, pribijen na križ, i u verziji gdje je obavijen bijelom svjetlošću, nakon uskrsnuća. Ta joj je bila najdraža. Bio je gotovo kao duh.

Pomislivši da frizerkina šutnja znači zbunjenost, muškarac joj uhvati pogled u ogledalu.

„Malo duže i s bradom,“ objašnjava, „ne predugačko, doduše. Da ne izgledam kao žena.“

Ona mu pilji u potiljak. Počeo je ćelavjeti. Za isusovku ipak treba nešto s čime se može raditi.

„Treba vam više kose ako želite izgledati kao Isus“, kaže.

„Ah, dobro,“ kaže muškarac, „može onda kao John Bon Jovi?“

\section{Bitka kod Hastingsa}

Mislio sam da će prve stvari koje ću zaboraviti biti gole činjenice: Bitka kod Hastingsa, točka ledišta vode, broj dana u veljači u prijestupnim godinama. Nije bilo tako. Prvo što je isparilo bili su osjećaji: ona neopipljiva tjeskoba kad ne znaš je li prostorija tu da bi se u nju ušlo ili iz nje izašlo, koga volim i koliko se na tu ljubav mogu osloniti kad se ne uspijevam sjetiti imena koje uz nju ide, kako sam došao u ovu sobu s navučenim zastorima, a još nisu ni tri sata. Nisam čak mogao naći način da kažem da sam zaboravio te stvari; samo zbrka riječi koje su bile ili predugačke ili prekratke za taj 
zadatak i stiskanje šaka kad riječi ne bi dolazile. Čak i tada gole su činjenice ostale i mogao sam sa sigurnošću reći: 1066. godine i nula stupnjeva i 28 dana u običnoj godini, 29 u svakoj prijestupnoj, što je bio sulud način da ti dam do znanja da sam izgubljen, kao da vilicom grabim juhu.

\section{Španjolski pingvin}

Sinoć smo naletjeli na španjolskog pingvina kako luta Cornmarketom. Padala je kiša, kao skoro uvijek u Belfastu, a on nije imao kišobran.

„Tražim mjesto s tradicijskom glazbom“, rekao je na lošem engleskom. Skoknuo je ovamo za vikend iz Madrida.

Odveli smo pingvina u Vojvodu od Yorka. Nedjeljom popodne tamo obično imaju tradicijsku glazbu . Trebalo nam je skoro pola sata da prepješačimo do druge strane grada, zbog njegovih vrlo kratkih nogu.

Kad smo stigli u Vojvodu, izbacivač nam je prilično odrješito rekao da je pingvinima ulaz zabranjen.

Pa smo mu rekli: „Došao je samo za vikend i nije li ovaj grad sada otvoren posjetiteljima?“

„A,“ rekao je izbacivač, „Žao mi je. Mislio sam da ste domaći pingvin. Pingvini turisti su iznimka. Hajde, uđite. Pit ćete Guinness, pretpostavljam?“

Španjolski pingvin popio je pintu Guinnessa, pa onda još jednu. Na trećoj je bilo očito da pingvini ne podnose alkohol jer je bio na stolu, izvodio svoju pingvinsku verziju flamenca i slikao se za Facebook.

\section{Plesna dvorana}

Kad nam je bilo šesnaest godina poslali su nas na satove plesa tamo u centru grada. Djevojke su išle u jednu dvoranu. Mi dječaci u drugu. Učili smo kako voditi. Učili smo kako slijediti ritam kao da je ritam tanka linija, a sa svake njezine strane strmoglavi ponor. Učili su nas da se djevojkama ne ispričavamo. Ako im gazimo po prstima to je zato što im se prsti nisu pomaknuli unatrag ili naprijed 
u pravo vrijeme. Nismo plesali jedan s drugim. To bi bilo suludo: da gotovo odrasli muškarci jedan drugog vode plesnim podijem držeći se za ručni zglob. Umjesto toga plesali smo u redovima, na vršcima se prstiju krećući oko fantomskih partnerica, ruku ispruženih prema njima, dok nam stopala razigrano dodiruju njihove zamišljene cipele.

Kad smo stasali dovoljno da zaslužimo partnerice, odveli su nas u dvoranu s djevojkama i raspodijelili nas u parove. Nismo morali razgovarati s njima. Naša su stopala već znala što treba reći. Bili smo kao dvodijelna harmonija koja se prvi put izvodi u komadu.

\section{Mudraci}

Jutros sam pročitala onu pjesmu Kay Ryan, onu o četvrtom mudracu koji nije volio putovati i draži mu je bio vlastiti krevet od otvorene ceste, što me podsjetilo na pastira koji je otišao na brzinu se olakšati baš u krivom anđeoskom trenutku, što me podsjetilo na sve ljude koji su, čuvši da samo jednu porciju štruca i ribe treba raspodijeliti na toliko njih, otišli kući slistiti vlastite sendviče, na goste koji su se napili do obnevidjela ispod stolova mnogo prije nego što se voda pretvorila u nešto poput vina, i naravno, na učenike koji su gotovo uvijek spavali u čamcima i u vrtovima i na drugim udobnim mjestima i sve propustili. I konačno sam se sjetila sebe i svih onih večeri kad sam odlučila ostati kod kuće gledajući reprize Morsea ili Poirota, u krevetu čitajući džepna izdanja romana, dok su se na ulicama i u barovima i na pozornicama ovog grada blaženo odvijala čuda, a ja za njih saznavala tek poslije, preko Facebooka.

\section{Čudovište iz Loch Nessa}

Jutros je uginulo čudovište iz Loch Nessa. Trebao joj je to biti devetsto tisućiti novi dan, no iako je stara cura voljela zaokruživati, nije joj se činilo da može izdržati još sto tisuća buđenja samo da dogura do punog milijuna.

Na kraju je nisu ubili ni metci, ni starost, čak ni skeptici koji sonarima i posebnim kamerama pokušavaju dokazati da ne postoji. Umjesto toga, vrlo specifična vrsta usamljenosti nagnala ju je da udahne i zadrži dah sve dok joj velika pluća nisu popustila, a oči joj se zauvijek zaklopile. Bila je to usamljenost onoga tko ostane zadnji nakon što su svi otišli kući. 
Do navečer čudovište iz Loch Nessa počet će nestajati: njezin će se čudovišni trbuh usukati u sebe, koža će joj omlohavjeti, a kosti će se razići i utonuti u pjeskoviti mulj. Manja i običnija bića oglodat će je ustima i zubima.

Do sutra neće ostati nikakvog dokaza da je čudovište iz Loch Nessa ikad postojalo. To ni na koji način neće utjecati na one (kako domaće tako i strance) koji su u stanju vjerovati u nešto što nikada nisu vidjeli. Oni će se i dalje nadati njezinu uvijenom vratu, koji se izvija svaki put kad se voda u jezeru digne.

\section{Usamljeni kaktus}

Na radionici pisanja kaže da radi na knjizi za djecu o usamljenom kaktusu.

„On stvarno želi naći prijatelje,“ objašnjava, „ili se možda i zaljubiti, ali svaki put kad se nekome približi, nanese mu toliko boli da ga napuste.“

Svi u grupi zašute. Neki razmišljaju o kaktusima. Većina ih razmišlja o tome kako je usamljeni kaktus metafora za više-manje svaku vezu koju su imali u odrasloj dobi. Počnu predlagati moguće rasplete za priču. Imaju i vlastite razloge da pronađu sretan završetak za usamljeni kaktus.

„Bi li mu bodlje mogle otpasti?“ upita jedan stariji muškarac. „Tako bi se mogao približiti drugima, a da ih ne povrijedi.“

Ne sviđa joj se ideja o kaktusu bez bodlji. Misli da bi to moglo zbuniti mlade čitatelje. Kako će prepoznati da je glavni lik kaktus ako bude ćelav?

„A kad bi usamljeni kaktus upoznao nekoga tko voli bol?“ upita mladić po imenu Simon. „I kad bi naučili biti sretni iako jednog od njih uvijek boli?"

Ona odbacuje i ovu ideju govoreći da to ne zvuči kao zaplet prikladan za knjigu za djecu. Potajno pomisli i da suviše podsjeća na stvaran život.

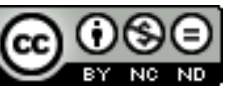

Creative Commons Attribution-NonCommercial-NoDerivatives 4.0 International License 